\title{
Psychological Justification of Using Authentic Fund of English Language by the Teachers at Secondary Schools
}

\section{Психологічне обґрунтування використання автентичного фонду англійської мови вчителями в середніх школах}

Oleksandr Hudyma

Ph.D. in Psychology, Assistant Professor

\section{Олександр Гудима}

кандидат психологічних наук, доцент

E-mail: hyduma1979@ukr.net orcid.org/0000-0001-8244-7284

Researcher ID: F-8900-2019

Kamianets-Podilskyi National

Ivan Ohiienko University, Kamianets-Podilskyi, Ukraine

61, Ohiienka street,

Kamianets-Podilskyi, Khmelnytskyi region, 32300

Alla Yatsiuryk Ph.D. in Psychology, Assistant Professor
Кам'янеиь-Подільський національний університет імені Івана Огієнка, м. Кал'янеиь-

Подільський, Україна вул. Огієнка, 61, м. Кам'янець-Подільський, Хмельницька обл., 32300

\section{Алла Яцюрик}

кандидат психологічних наук, доцент

E-mail:yatsiuryk.a@gmail.com orcid.org/0000-0003-3933-8503

Researcher ID: F-3174-2019

International University of Economics and Humanities named after Academician

Stepan Demianchuk

4, Stepan Demianchuk Str., Rivne, Ukraine, 33000
Міжнародний еконолікогуманітарний університет ілені акаделіка

Степана Дем'янчука вул. Степана Дем'янчука, 4 , м. Рівне, Україна, 33000 
Original manuscript received April 27, 2019

Revised manuscript accepted May 18, 2019

The author's contribution: O. Hudyma $-50 \%$, A. Yatsiuryk $-50 \%$. Авторський внесок: О. Гудима - 50\%, А. Яцюрик - 50\% .

\section{ABSTRACT}

The psycholinguistic analysis of English proverbs and sayings with the component of "human activities» is made in the article. It is determined that existential phenomenology corresponds to a functional-communicative, cognitive and anthropogenic paradigm of the research of these lexical units of the English language. The latter one generates a series of psycho-linguistically predetermined processes.

The first process is actualization of the reader's intuition as a kind of "presence» of the essence of the object having been studied in a mind of a subject, "without ideological», "self-serving" presentation, due to intentional contemplation and understanding of its eidos. It was indicated that that moment, in turn, was largely due to the authenticity of the materials having been studied. The second process is a peculiar "subjectivization» of lexical material having been studied, when the reader seems to "reduce» himself / herself implicitly, his / her essence, his / her personal meaning in the language. The latter one allows the reader to "stay" in a paradigm of a language, "passing through brackets» only priori judgments about a particular object of the research. It was indicated that it contributed to reduce the "distance» between the image of the reader's world and the meaning that was embodied in a particular proverb or saying. It was shown that the latter, in turn, greatly facilitated the reproduction of the subject-object unity between the image of the reader's world according to absorbed material that deepened the mental picture of the subject's world.

The third process is authentic intersubjectivity, which can be interpreted as a peculiar basis of the personality, the basis of human existence in the world, the existence of the society, etc. It was shown that the authentic material created positive conditions for the existence of so-called "egocentric particles", which each person, after mastering, applied in his / her own language. It was indicated that such "egocentric particles" included discursive words, the research of which was maximally productive in the study of proverbs and sayings. Consequently, authentic intersubjectivity greatly stimulates the study of a real process of functioning of a language from the point of view of the subject of communication. 
The fourth process is the authentic intentionality as the essence of consciousness, its orientation to a particular object of the research. It was substantiated that the authentic intentionality is the property of the consciousness of the person, by means of which its states are characterized as some structures which are containing content, authentic information that is beyond the consciousness of a man, in the paradigm of a mental space of the Universe.

Key words: psycholinguistic analysis, authenticity of the material, proverbs, sayings, intuition, "subjectivization" of studied material, authentic intersubjectivity, authentic intentionality.

\section{Introduction}

Authentic fund of the language is a treasury of folk wisdom, which includes the most apt, capacious, artistically expressive words-observations that touch upon all the most essential spheres of life and human activity. This fund is an open system, because it is constantly replenished at the expense of well-known aphorisms of public figures, artists, writers and scholars who so often use these figures of speech in the media and everyday communication, which eventually lose their authorship and become a national heritage. Acquiring aphorism for the proverb's status is not only, and not in a large degree, due to its direct meaning. In such a way the teacher has to take into account the way of expression of thoughts, the form that serves as a mean of embodying new semantic meanings. The latter breeds the language of folklore with poetic speech, which, according to classical expressions, represents «the best words in the best order». Each proverb is, in essence, a miniature artistic product, the content and aphoristic force of which are generated by its condensed imagery and peculiarities of the rhythm-molecule structure.

Recently in psychological science interest to authentic fund has increased, because the researchers contain reflections of deep myths and archetypes of human consciousness that can be manifested both in ancient folk structures and in modern stamps of mass consciousness (advertising, ideological texts, PR-technologies, etc.). Also authentic fund reflects 
the totality of thoughts made by the people as a linguistic and cultural community, and makes it possible to identify significant mental values of an ethnic group.

A large number of studies of authentic fund show the constant interest of scientists to this phenomenon. As an integral part of the spiritual culture, proverbs and sayings, with all their versatility, manifest in a number of languages a certain specificity of verbalization, due to the subjectivity inherent to the speakers of the interpretation of the surrounding reality, which continues to cause interest.

So, the purpose of our research is: to provide psycholinguistic analysis of English proverbs and sayings with the component «human activity», to assert that existential phenomenology corresponds to a functional-communicative, cognitive and anthropogenic paradigm of the research of these lexical units of the English language, to generate a series of psycho-linguistically predetermined processes.

\section{The tasks of our research}

1. To distinguish psychological content of such lexical units as proverbs and sayings.

2. To make psychological justification of using authentic fund of the language by the teachers of English at secondary schools.

\section{Research methods}

The following methods were used in this article: theoretical analysis, generalization and systematization of researches of authors according to the problem of psychological justification of using authentic fund of the language by the teachers of English at secondary schools.

\section{Results and discussions}

Capacity and informativeness are the essential qualities of a linguistic sign, which underlies its most important functions along with communicative and cumulative functions. 
The language is as a link between generations, is a so called «repository» and a means of transferring extra-language collective experience.

First of all, the vocabulary reflects fragments of social experience, due to the main activities of people. The existence of these ones or other lexical units is explained by practical needs. The connection of the history and culture of the people with the language is particularly pronounced at a phraseological level. A large number of proverbs and sayings reflect specific national traits, their roots go deep into the history of people, their life, customs and traditions.

In psycho-linguistics, the development of the theory of asymmetrical dualism of a linguistic sign is seen in a promising direction, according to which a plan of expression and a plan of contents sometimes violate the principle of a oneto-one correspondence between denotatum and syndicate (Mykhalchuk, 2017).

Carefully selected vocabulary and the structure of the statement form not only the content but also the perception of the event. So, well-used vocabulary of feelings allows us to look into the inner psychic world not only of the depicted person with his / her feelings and emotions, but also shows the personality of the author. An empirical reality is infinitely diverse, and, therefore, the structure of proverbs and sayings is equally mobile and unpredictable. That's why proverbs and sayings was the material of our research as authentic material and authentic tasks for pupils at the English lessons at a contemporary secondary school.

In this part of our research we'd like to present the analysis of pupils' authentic materials. Such kind of material was for us the paradigm of English proverbs and sayings with the component of «human activity». Such kind of material is psychologically investigated, that's why it was a subject of our research.

Also it is well-known that each novel is the act of speech, and therefore represents a certain sequence of sounds, a se- 
quence of words, phrases or sentences. The effect of the text on the listener is achieved through the sound side of a proverb, which is one unit with the rhythm and its meaning, and separately subdivided parts of proverbs can not affect the listener.

Proverbs and sayings are miniature artistic works of oral folk art. Various stylistic means are found in their structure, and euphonic means are not exceptions. When we tell about euphonic means we mean rhymed consonants, alliterations and assonances, which are more important expressive means contributing to the stability of structure of proverbs and closely interacting with their sense and value.

Psychological content of these lexical units in a large degree is reached by rhyme of proverbs and sayings. Rhyme, the consonance of endings, is an extremely important character of proverbs, which reflects, at the same time, the musical sense of people, their subconscious desire for attitude of fullness and beauty of sounds. Rhyme gives so called completed form of a proverb, conquers the structure, makes proverb (of course, relatively) immobile and at the same time this lexical unit can easily fall into our memory.

Rhymed consonance is also widespread in proverbs and sayings. In proverbs there are rhymes of different types, such as: full male, exact or identical male rhyme, full female rhyme. Let's consider these types of rhymes in more details.

In a case of full man's rhyme the repetition is created by a monosyllable token with the coincidence of loud rhymes of all subsequent sounds. This type of rhymes is predominant in English rhymed proverbs. As examples we can show the following proverbs:

One always learns at his own expense.

(Власний досвід - найкращий учитель).

No living man all the things can.

(Мудрил ніхто не вродився, а навчився).

Man of words and not of deeds is like a garden full of weeds. 
(Любитель слів і ворог діл схожий на грушу без плодів). (The dictionary «Multitran», 2018).

Accurate or identical male rhyme differs from the previous one by the fact that consonant, a loud one, and all other sounds are presented in a coincide paradigm. In English rhymed proverbs repeating sounds are parts of a sound complex with one person is talked. These sounds make up a whole sound complex of a listener, for example:

There's many a slip twixt cup and lips.

(Не говори «гоп», доки не перескочиш).

It is better to be spited than pitied.

( Краше викликати заздрість, ніж жалість).

(The dictionary «Multitran», 2018).

A female rhyme is observed in proverbs more rarely than a male one, but there are some examples in the English language. In a full feminine rhyme one accentuated and one undeclared composition are repeated in the concurrence of a vowel of accentuated composition and all other subsequent sounds, for example:

No bees, no honey; no work, no money.

(Без труда нела плода).

(The dictionary «Multitran», 2018).

Also schoolchildren said that rhyme was the second most frequent use of a phonetic stylistic device. Psychological content of proverbs and sayings in a great degree is made by alliteration. The phenomenon of alliteration is very common in the structure of proverbs. Alliteration in a broad, general sense is a repetition of vowel and consonant sounds in the beginning of closely located accented syllables. By its nature, there are different types of alliteration, but the most common is the alliteration with the repetition of one sound. For example:

Where there is a will there is a way.

(Де охота- тал і робота).

He that will eat the kernel must crack the nut.

(Треба нахилитися, щоб із криниці води напитися). 
What we do willingly is easy.

(Де руки і охота, тал спора робота).

No sweet without some sweat.

(Пороби до поту, то й поїси в охоту).

(The dictionary «Multitran», 2018).

In a compositional structure of proverbs and sayings we can distinguish the following subtypes of this type of alliteration:

1) repetition of the consonants in the first and the last words:

Live and learn.

Look before you leap.

( Не знаючи броду, не сунься у воду).

Practice makes perfect.

(Робота вчить).

Let the cobbler go beyond his last.

(Швець, знай своє шевство, а в кравецтво не лізь).

(The dictionary «Multitran», 2018);

2) repetition of the consonants in the second and the last words:

One swallow doesn't make a summer.

(Одна ластівка весни не робить).

(The dictionary «Multitran», 2018);

3 ) repetition of two or three consonants in different structures:

Fast bind, fast find.

(Як дбаєш, так імаєи).

Better never begin than never make an end.

Cut your coat according to your cloth.

Good master makes good servant.

( Краще не починати, ніж не закінчити).

(The dictionary «Multitran», 2018).

Repetition of two sounds in the structure of proverbs and sayings.

In the structure of proverbs and sayings there is another type of repetitions. It is a repetition of two sounds. This type is found in proverbs rarely, for example: 
No sweet without some sweat.

(Без труда нела плода).

(The dictionary «Multitran», 2018).

Also there is a combination of alliteration with rhymes in the structure of proverbs and sayings, for example:

A stitch in time saves nine.

(Один стібок, зроблений вчасно, коштує дев'яти).

(The dictionary «Multitran», 2018).

Rhyme is based on the repetition of the diphthong [ai] and the proximity of closed sonants [m] and [n].

Another stylistic device which in a great degree makes psychological content of proverbs and sayings is the assonance. One word is repetition of the accented headlines in a line or a phrase, or at its end in a form of incomplete rhymes. We'll give the examples:

Haste makes waste.

(Поспішиш - людей наслішиш).

(The dictionary «Multitran», 2018).

In the first proverb, the assonance is achieved by the repetition of the diphthong [ei].

Another example of the assonance may be such a proverb:

Make hay while the sun shines.

(Коваль клепле, доки тепле).

(The dictionary «Multitran», 2018).

In the second example the assonance is achieved by repeating the accentuated diphthong [ai], in words «while», «shine», and diphthong [ei] in the words «make», "hay». After analyzing the cases of using the assonance as a part of proverbs we found that it is not common, assonance is used less than alliteration.

In proverbs and tales there are different types of phonetic stylistic devices, but we've to pay special attention to the rhyme, because, as a rule, all proverbs and sayings are rhythmically organized and rhyme expressed. Also psychological emphasis of proverbs and sayings is made by syntactic features of lexical units. Syntactic features of proverbs 
are supported by lexical and euphonic expressive means. The artistic form of proverbs has evolved for centuries. For example, R.Langacker very aptly said according to this subject that the proverb was created by mutual forces of our sounds and thoughts (Langacker, 1991).

Also N.Mykhalchuk (Михальчук, 2012) thinks, that proverbs are the formulas of natural observation and reflection, which are settled as they are. With all these differences in the conditions of their changes, for proverbs in the most cases they are characterized by a persons' conciseness, which is expressed in the most accurate and concise form, thanks to which the words are tight, and thoughts are spacious.

The main lexical-syntactical pictorial means can be considered by repetitions and comparisons. Also repetitions perform the main psycho-linguistic function in the structures of proverbs and sayings. Letters that are repeated are certainly not worth close. There are various types of repetitions.

1. Repetition of tokens standing in the first place. Significant, as well as legendary tokens, can be enlisted: First come, first served - Першого першили і обслуговують - reduction of outdated lexical unit ( $\mathrm{He}$ who is first come is first served).

Handsome is as handsome does.

(По-справжньолу красивийлише той, хтогарновчиняє). Nothing venture, nothing have.

(Без ризику нелає перелоги).

Such carpenters, such chips.

(Який Сава, така й слава).

(The dictionary «Multitran», 2018).

Proverbs with a ring repetition are used only in some cases. Money makes money.

(Гроші роблять гроші).

(The dictionary «Multitran», 2018).

2. Repetition of lexemes which stands at the second place: As you brew, so must you drink.

(Як постелиш, так і виспишся).

(The dictionary «Multitran», 2018). 
3. Repetition of lexemes which are standing at third place. In this type of repetition, which is used rarely, usually are repeated immaterial parts of lexical units:

He that never climbed, never fell.

(Хто не літав, той не падав).

Where there is a will there is a way.

(Де хотіння, там і вміння).

(The dictionary «Multitran», 2018).

4. Repetition of the lexical units which stand at the fourth place. This type of repetition takes a place extremely rare:

If two men ride on a horse, one must ride behind.

( Коли двоє їутьь на однолу коні, то однолу завжди доводиться сидіти ззаду ).

(The dictionary «Multitran», 2018).

Repetition of two equal parts of lexical units. This type of repetition is also rare:

So many men, so many minds.

(Скільки голів, стільки і дулок).

(The dictionary «Multitran», 2018).

It is possible to repeat two initial insignificant parts of lexical units:

Out of sight, out of mind.

(Геть з очей, геть із серия).

(The dictionary «Multitran», 2018).

In a proverb In for a penny, in for a pound - Узявся за гуж, не кажи, що не дужий (The dictionary «Multitran», 2018) three indescribable parts of lexical units are repeated. A great psychological role plays a comparison in the structure of proverbs and sayings. Comparison can be divided into two groups. The first one is antonymic comparisons, the second one is comparison as a combinations of lexical units that are not antonyms according to the meaning of this or that proverb.

1) Antonymic comparisons, that is, the comparison of lexemes, which are antonyms beyond the structure of given proverb: 
He that is full of himself is very empty.

(Той порожній, хто повний салил собою).

Who has never tasted bitter, knows not what is sweet.

( Не покуштувавши гіркого, не взнати і солодкого).

(The dictionary «Multitran», 2018).

Antonymic comparison is widely used in comparative proverbs:

Better to reign in hell than serve in heaven.

(Краще керувати в пеклі, ніж прислуговувати в раю).

(The dictionary «Multitran», 2018).

In the last proverb, a combination of antonymic comparison of structural parts is used in «reign in hell and serve in heaven». In proverbs it is possible to combine repetition with antonymic comparison:

He that never climbed, never fell.

( Не пізнавши зльотів, не взнаєш і падінь).

(The dictionary «Multitran», 2018).

2) Comparison as a combinations of lexical units that are not antonyms according to the meaning of this or that proverb:

A bird in hand is worth two in bush.

( Краще синищя в руках, ніж журавель у небі).

(The dictionary «Multitran», 2018).

Similar types of comparisons are found in comparative proverbs:

Better an egg today than a hen tomorrow.

( Краще яйе сьогодні, ніж курка завтра).

Half a loaf is better than no bread.

(Півкоровая краще, ніж зовсім нічого).

(The dictionary «Multitran», 2018).

The desire to understand the meaning of proverbs is very difficult when we have a deal with elliptical proverbs. The widespread use of lexical and euphonic means in proverbs is according to the expression of people's nationality, which, in turn, facilitates proverbs and sayings to be more clearly transmitted. 
To analyze psychological aspect of proverbs and sayings we'd like to distinguish their lexical-semantic aspect. Proverbs and sayings for many centuries reflected the religious and mythological imagination of people, worldview and rules of behavior, the role of other cultures and their value in the past. Due to the fact that proverbs and sayings have a profound universal meaning that goes beyond the historical epoch in which they were created, they acquired aesthetic and didactic value. The theme of proverbs depends on a certain extent on all social phenomena and factors. Man seeks to express with the help of folklore all the imagination contained in his mind. This collection of ideas is contained in the vocabulary of each language, and it must be noted that each nation has its circle of vision, inherent only to representatives of this language group. The last in a great degree differs from others and has its individual characteristics. These differences are particularly noticeable in relation to the aesthetic and moral assessment of the world. It is impossible to reduce to only one indisputable concept, because it is clear that all people understand beauty, disaster, kindness, love, charity, squatting, generosity, and these characteristics have deep psychological meaning and sense. All these concepts are reflected in the paremiological fund of people.

We must remember that proverbs and sayings have both direct and figurative significance. These characteristics of lexical units are an important sign, because a wrong interpretation of each proverb changes its meaning. For example: As you sow, so shall you reap - Як посієu, так і пожнеш (The dictionary «Multitran», 2018) - has both direct and figurative significance. If a person is lazy and has not done anything in spring, then in autumn he / she will have nothing; if you behave badly with other people, then they will treat you in a same way.

Figurative meaning is metaphorical and metonymic. Analyzing English proverbs you can identify groups of words, with which the English language reflects the person's atti- 
tude to a certain phenomena. The figurative basis of proverbs in English is represented by such words, as: eyes (oчi), head (голова), heart (серце), arm (рука), foot or leg (нога). There are a lot of proverbs which show the definition of parts of body, which are obviously due to the presence of certain elements in the environment, the sense of unity of a man with nature, have anthropological imaginations, which led to the analogy of human actions, but with similar in nature, and that helps to provide the typization of such phenomena.

In proverbial units, when the word «head» (голова) appears, it refers to a human mind, the man himself. Therefore, often the words with supporting words "head» and «mind" mutually reciprocate. The intelligent head metonymically represents a wise man, it is opposed to a stupid head - a limited man:

1. Two heads are better than one.

(Одна голова добре, а дві краще).

(The dictionary «Multitran», 2018).

In figurative meaning, this reference word can also be used to determine leadership, seniority:

Fish begins to stink at the head.

(Риба починає слердіти від голови).

(The dictionary «Multitran», 2018).

Proverbs with a word «hand» (рука) have the mostly portable value. The «hand» in proverbs symbolizes human labor, mutual respect, reveals the relationship between people.

One hand washes the other.

(Одна рука другу миє).

(The dictionary «Multitran», 2018).

In a separate thematic group there are proverbs with supporting words «experience» (уміння), «learn» (навчання). They are used in direct and figurative meanings, for example. Experience keeps no schools, she teaches her pupils singly. (У досвіду нелає загальної школи, він навчає своїх учнів окрело).

It is never too late to learn. 
(Учитися ніколи не пізно).

Live and learn.

(Жити та вчися).

Learn to creep before you leap.

(Навчися повзати раніш, ніж стрибати).

Learn to say before you sing.

(Спочатку навчися говорити, а потіл співати будеш ).

Learn wisdom by the follies of others.

(Учися жудрості на чужих полилках).

(The dictionary «Multitran», 2018).

As it has already been noted, the proverbs are often used in their figurative meaning. Relative stability of portable value of proverbs makes it possible to use them in relation to constant changing social, economic and living conditions. Proverbs' shaped basis and poetic form is transmitted from generation to generation and expresses national specificity. For example:

Who keeps company with wolf, will learn to howl.

(Хто водиться з вовкали, навчиться вити).

(The dictionary «Multitran», 2018).

With the help of a figurative basis of this proverb, a person gives some experience to his / her descendants. The proverb teaches that if a person finds himself / herself in a bad company and he / she is surrounded by bad people, he / she also becomes the same as they are.

One swallow does not make a summer.

(Одна ластівка не робить літа).

(The dictionary «Multitran», 2018).

The proverb says that one can not achieve something alone, but we have to do everything together, calls everybody for unity. Such English proverbs as:

Strike while the iron is hot.

(Куй залізо, поки гаряче).

Make hay while the sun shines.

(Коси сіно, поки соние світить).

(The dictionary «Multitran», 2018). 
have the same meaning. It means that a person must do everything on time. But we see that they have a difference in the figurative basis of these proverbs and sayings.

Literal translation gives us the opportunity to imagine something, which lies at the basis of the proverb, to understand its internal form, and with the help of a figurative basis, to know a national specificity which has been expressed. Also we'll consider the above named trails in more details.

We've to underline that the word, which is used figuratively, is called a metaphor. Metaphor is a lexical pictorialexpressive stylistic mean in which a word or a phrase is used in figurative meaning. In Stylistics under the metaphor is understood the principle of unusual use of a name of the «subject», «essence», «object», which can be affixed to it forever. O.Potebnia understood under the metaphor the process of transference of the third word (that is, words with a different meaning in relation to the value we seek): a) either from genus to species; b) either from species to species; c) or from species to species; d) or by correspondence (similarity).

A need to use the metaphor in the statement is particularly evident in those cases where it expresses complex and indistinct series of thoughts, excited by an indefinite set of actions, words, events. Since proverbs and sayings express the diversity of events and phenomena of a society, the use of metaphors in their structure is appropriate and necessary. For example:

a) A drowning man will catch at a straw.

(Xmo nomonae, mой за косу xanaє).

(The dictionary «Multitran», 2018).

As a part of this proverb there is a metaphor represented by a phraseological unit: "To catch at a straw».

b) If you run after two hares, you will catch neither.

(Хто два зайці гонить, жодного не впійлає).

Between two stools one falls to the ground.

(Двол господарял не прислуговують).

(The dictionary «Multitran», 2018). 
In this example, there are metaphors: "to run after two hares», "between two stools». The first proverb is quite metaphorical. With the aid of metaphors, the view is expressed that a person who is hesitant in choosing loses all the possibilities to achieve something.

An old broom knows the corners of a house.

(Старий віник знає усі закутки у долі).

Old foxes want no tutors.

(Не вчи кота ученого їсти хліба печеного).

Don't teach fishes to swim.

( Не вчи вченого).

(The dictionary «Multitran», 2018).

A person who has lived for a long time or understood his / her business well does not need any advice from someone else's hand, because he / she so well understood at all. It is precisely that this meaning laid in the metaphors of given proverbs.

We think, that depending on the features of semantics, as a rule, there are two types of metaphors - linguistic and psycho-linguistic. However, although this distinction is generally accepted, it is hardly possible to establish clear boundaries between them. The linguistic metaphors originate from a specific text and they are always associated with it, since the connotative features that serve as a motive for rethinking the verbal meaning are formed within the given lexical set (sentences or entire text). Such connotations reflect, in the most cases, not the collective, but the individual vision of the world, in such a way they are subjective and random relative to a general meaning. Since proverbs and sayings are a process of reflection of collective (but not individual experience), such kind of metaphor in their structure was almost not found by us (we mean the proverbs with lexical units which show individual experience of people).

The analysis of proverbs and sayings at the English lessons facilitates us to make a conclusion that a metaphor is in the structure of these lexical units more often than other stylistic means. The second most frequent use of proverbs is 
their stylistic meaning, it is metonymy. Metonymy is based on a real connection of the object of the nomination to the object whose name is transferred to the other object. This connection may be between the subject and the material from which it was made; between the place and the people who are in it; between the process and its result, between the action and the tool, and so on.

In proverbs and sayings it was shown the metonymic connection between feeling and the implementing body, between the body and the person in a definite place. For example:

One hand washes another.

(Рука руку лиє).

Many hands make quick work.

(Де згода, тали і вигода).

(The dictionary «Multitran», 2018).

The epithet, which also takes place in a structure of proverbs, is lexico-syntactic mean, because it serves a function of circumstance, definition or appeal. It does not necessarily have a figurative meaning, but we have to emphasize expressive and emotional connotations, which expresse the relations of a man to this or that subject.

The meaning of the epithet arises in a word only in a case of conjunction with a name of an object or the phenomenon it defines. Very often the function of epithets is the same as of adjectives and adverbs. Here are some examples:

Nothing venture, nothing have.

(Де відвага, там щастя).

Fortune favours the brave.

(Дулка п’є воду, а відвага лед).

(The dictionary «Multitran», 2018).

It should be noted that epithets are not often in the structure of proverbs and sayings.

Thus, doing our research, we found that stylistic means in the structure of proverbs and sayings by their nature are diverse and numerous, and the vast majority of them are based on a principle on which all mechanisms of the English lan- 
guage are constructed: the comparison of phenomena and the establishment of similarity (equivalence) or difference (contrast) between them.

At the same time it should be noted that against the backdrop of the widespread use of stylistic means and tropes in proverbs and sayings, the specifics of using of pictorial and expressive means are determined, for the most part, on the basis of frequently used indexes of their use in the structure of British proverbs: a) at a phonetic level: alliterations (14\% ); rhyme (6\%); assonance $(3 \%)$; b) at a lexical-syntactic level: comparisons (10\%); repetitions (8\%); c) at a lexical-semantic level: metaphors (32\%); metonymies (9\%); epithets (7\%).

It also becomes clear that the most important role in creating expressiveness and in enhancing the image of proverbs and sayings is played by a connotation that gives a word or a phrase emotional, expressive and evaluative content, and the latter, in its turn, can be as negative so positive.

Thus, we found that the use of tropes and stylistic means in the structure of proverbs and sayings creates a figurative basis in their meaning, making proverbs and sayings so called «frozen» linguistic unit, and a connotation enhances expressiveness, giving to these lexical units a necessary expressive shade.

\section{Conclusions}

Consequently, our psycholinguistic analysis of English proverbs and sayings with the component of "human activity" allows us to assert that existential phenomenology (Бацевич, 2010) corresponds to a functional-communicative, cognitive and anthropogenic paradigm of the research of these lexical units of the English language. The latter generates a series of psycho-linguistically predetermined processes, they are:

1) actualization of the reader's intuition as a kind of "presence» of the essence of the object having been studied in a mind of a subject, "without ideological», "self-serving» presentation, due to intentional contemplation and understan- 
ding of its eidos. This moment, in turn, is largely due to the authenticity of the materials having been studied;

2) a peculiar "subjectivization" of lexical material having been studied, when the reader seems to «reduce» himself / herself implicitly, his / her essence, his / her personal meaning in the language. The latter allows the reader to "stay" in a paradigm of a language, "passing through brackets» only priori judgments about a particular object of the research. This contributes to reduce the "distance» between the image of the reader's world and the meaning that is embodied in a particular proverb or saying. The latter, in turn, greatly facilitates the reproduction of the subject-object unity between the images of the reader's world according to absorbed material that deepens the mental picture of the subject's world. In the process of the phenomenological development of subject-object unity, the language appears as a psycholinguistic factor in reduction of priori components of thinking and consciousness, as E. Husserl (Гуссерль, 2001), the founder of phenomenology, considered language as some ideal objectivity;

3) authentic intersubjectivity, which can be interpreted as a peculiar basis of the person, the basis of human existence in the world, the existence of the society, etc. According to the definition proposed by Yu. Stepanov (Степанов, 1981) the authentic material creates positive conditions for the existence of so-called «egocentric particles», which each person, after mastering, applies in his / her own language. Such «egocentric particles» include discursive words, the research of which is maximally productive in the study of proverbs and sayings. Consequently, authentic intersubjectivity greatly stimulates the study of a real process of functioning of a language from the point of view of the subject of communication;

4) the authentic intentionality as the essence of consciousness, its orientation to a particular object of the research. Thus, the authentic intentionality is the property of the consciousness of the person, by means of which its states are characterized as some structures which are containing 
content, authentic information that is beyond the consciousness of a man, in the paradigm of a mental space of the Universe. The latter allows us to speak about the authenticity of the Universe, which combines the subjective states of the person with the rest of the world, and his / her own and other people's psychic activity will be interpreted in purely intentional terms.

\section{Literature}

Бацевич Ф. Нариси з лінгвістичної прагматики. Львів : ПАІС, 2010. $336 \mathrm{c}$.

Гуссерль Э. Картезианские размышления. Санкт-Петербург : Наука, 2001. C. 69-70.

Михальчук Н. О. Пареміологічні одиниці з компонентом «діяльність людини» як об’єкт когнітивної лінгвістики. Мова і культура. Київ : Видавничий дім Дмитра Бураго, 2012. Вип. 15. Т. 6 (160). C. $105-112$.

Mykhalchuk N. O. Psychological context of the idea of understanding. Пcuхолінгвістика. Психолингвистика. Psicholinguistics. Зб. наук. пр. ДВНЗ «Переяслав-Хмельницький державний педагогічний університет імені Григорія Сковороди». Переяслав-Хмельницький : ФОП Домбровська Я. М., 2017. Вип. 22 (1). С. 163-175.

Степанов Ю. С. В поисках прагматики (проблема субъекта). Известия АН СССР. Серия «Литература и язык». 1981. Т. 40. № 4. С. 325332.

Langacker, R. (1991). Concept, Image and Symbol: The Cognitive Basis of Grammar. Berlin : Mouton de Gruyter. 395 p.

The dictionary «Multitran» (2018). Retrieved from http://www.multitran.com.

\section{References}

Batsevych, F. (2010). Narysy z linhvistychnoi prahmatyky [Essays on linguistic pragmatics ]. Lviv : PAIS [in Ukrainian].

Husserl, E. (2001). Kartezianskie razmyshlenija [Cartesian Reflections]. Sankt-Peterburg : Nauka [in Russian].

Mykhalchuk, N. O. (2012). Paremiolohichni odynytsi z komponentom «diialnist liudyny» yak obiekt kohnityvnoi linhvistyky [Paremiological units with the component of «human activities» as the object of cognitive linguistics]. Mova i kultura - Language and culture, 15, 6 (160), 105-112. Kyiv : Vydavnychyi dim Dmytra Buraho [in Ukrainian]. 
Mykhalchuk, N. O. (2017). Psychological context of the idea of understanding. Psykholinhvistyka. Psiholingvistika. Psycholinguistics. Zb. nauk.pr.DVNZ «Pereiaslav-Khmelnytskyi derzhavnyi pedahohichnyi universytet imeni Hryhoriia Skovorody» - Psycholinguistics. Collection of scientific articles of Pereyaslav-Khmelnytskyi State Pedagogical University named after Hryhoryi Skovoroda ], 22 (1), 163-175. Pereiaslav-Khmelnytskyi : FOP Dombrovska Ya. M. [in English].

Stepanov, Ju. S. (1981). V poiskax pragmatiki (problema subjekta) [In search of pragmatics (the problem of a subject)]. Izvestija AN SSSR. Serija «Literatura i jazyk» - Newsletter of the USSR Academy of Sciences. Series "Literature and Language», 40, 4, 325-332 [in Russian].

Langacker, R. (1991). Concept, Image and Symbol: The Cognitive Basis of Grammar. Berlin : Mouton de Gruyter.

The dictionary «Multitran» (2018). Retrieved from http://www.multitran.com.

\section{Гудима Олександр, Яцюрик Алла. Психологічне обгрунтування використання автентичного фонду англійської мови вчителями в середніх школах}

\section{АНОТАЦІЯ}

У статті здійснено психолінгвістичний аналіз англійських прислів'їв $і$ приказок із компонентом «діяльність людини». Визначено, що функціонально-комунікативній, когнітивно- і антропозорієнтованій парадигмі досліджень парамеологічних одиниць мови відповідає екзистенційна феноменологія. Остання породжує низку виокремлених авторами статті психолінгвістично зумовлених прочесів.

Перший процес - актуалізація інтуїції читача як своєрідна «наявність» сутності досліджуваного об'єкта в свідомості суб'єкта, "безідеологічна», "самочинна» ії презентація у силу глибокого інтенційного споглядання та розуміння ії ейдосів. Зазначено, що цей момент великою мірою пояснюється автентичністю матеріалів, що вивчаються.

Другий прочес пов'язаний зі своєрідною “суб'єктивізачією» вивченого лексичного матеріалу, коли читач ніби імпліцитно "редукує» себе, свою сутність, свій особистісний зміст у мові. Останнє дає змогу читачеві ніби «перебувати» в мові, «виносячи за дужки» лише апріорні судження щодо певного об'єкта дослідження. Зазначено, що це сприяє зменшенню "відстані» між образом світу читача й тим змістом $i$ сенсом, який закладений у певному прислів'ї чи приказці. Визначено, що останнє, в свою чергу, значною мірою уможливлює відтворення 
суб'єкт-об'єктної єдності між образом світу читача та прочитаним й опанованим матеріалом, що поглиблює ментальну картину світу суб'єкma.

Третій процес визначено як автентичну інтерсуб'єктивність, що може тлумачитися як своєрідна основа особистості, основа буття людини в світі, існування суспільства тощо. Зазначено, що автентичний матеріал створює позитивні передумови для існування так званих "егоцентричних часток», які кожна людина, після їхнього опанування, застосовує у своїй мові. Визначено, що до таких "егоцентричних часток» належать і дискурсивні слова, дослідження яких є максимально продуктивним у межах вивчення прислів'їв і приказок. Наголошено, що автентична інтерсуб'єктивність великою мірою стимулює вивчення реального функціонування мови з точки зору суб'єкта.

Четвертий процес визначено як автентичну інтенціональність як саму по собі сутність свідомості, їі скерованість на певний об'єкт вивчення. Обгрунтовано, що автентична інтенціональність є властивістю свідомості особистості, за допомогою якої ії стани характеризуються як такі, що містять зміст, автентичну інформацію, яка є поза свідомістю людини, в парадигмі ментального простору Всесвіту.

Ключові слова: психолінгвістичний аналіз, автентичність матеріалу, прислів'я, приказки, інтуїція, "суб'єктивізація" вивченого, автентична інтерсуб'єктивність, автентична інтенціональність.

\section{Гудыма Александр, Яцюрик Алла. Психологическое обоснование использования аутентичного фонда английского языка учителями в средних школах}

\section{АННОТАЦИЯ}

В статье осуществлен психолингвистический анализ английских пословии и поговорок с компонентом «деятельность человека». Определено, что функционально-коммуникативной, когнитивно- и антропоориентованной парадигмам исследований парамеологических единии языка соответствует экзистенциальная феноменология. Последняя порождает ряд выделенных авторами статьи психолингвистически обусловленных процессов.

Первый процесс - актуализация интуиции читателя как своеобразное "наличие» сущности исследуемого объекта в сознании субъекта, "безидеологическая", "самовольная» его презентация в силу глубокого интенционального созерцания и понимания её эйдосов. Отмечено, 
что именно этим во многом объясняется аутентичность материалов изучаемого языка.

Второй процесс связан со своеобразной "субъективизацией» изученного лексического материала, когда читатель как бы имплицитно «редуцирует» себя, свою сущность, свой личностный смысл в языке. Последнее позволяет читателю как бы «находиться» в языке, «вынося за скобки» только априорные суждения относительно определенного объекта исследования. Указано, что это способствует уменьщению "расстояния» между образом мира читателя и тем содержанием и смыслом, которые заложены в определенной пословице или поговорке. Определено, что последнее, в свою очередь, во многом соответствует воспроизведению субъект-объектного единства между образом мира читателя и прочитанным и освоенным материалом, углубляет ментальную картину мира субъекта.

Третий процесс определен как аутентичная интерсубъективность, которая может быть истолкована как своеобразная основа личности, основа бытия человека в мире, а также как существование общества. Отмечено, что аутентичный материал создает положительные предпосылки для существования так называемых «эгоцентричных частиц», которые каждый человек, после их освоения, применяет в своей речи. Определено, что к таким «эгочентричным частицам» относятся и дискурсивные слова, исследование которых в максимальной степени является продуктивным в рамках изучения пословии и поговорок. Отмечено, что аутентичная интерсубъективность во многом стимулирует изучение реального функционирования языка с точки зрения субъекта.

Четвертый процесс определен как аутентичная интенциональность как сама по себе сущность сознания, его направленность на определенный объект изучения. Обосновано, что аутентичная интенциональность является свойством сознания личности, с помощью которой её состояние характеризуется как содержание, аутентичная информация, существующая вне сознания человека, в парадигме ментального пространства Вселенной.

Ключевые слова: психолингвистический анализ, аутентичность материала, пословицы, поговорки, интуиция, "субъективизация" изученного, аутентичная интерсубъективность, аутентичная интенциональность. 